\title{
Petrophysical Evaluation of Reservoir Sand Bodies in Kwe Field Onshore Eastern Niger Delta
}

\author{
ASUBIOJO, TM; OKUNUWADJE, SE \\ Department of Geology, University of Benin, P.M.B 1154, Benin City, Nigeria \\ Authors'Emails: asubiojomike@gmail.com; sunny_okunu@yahoo.com
}

\begin{abstract}
Reservoir sand bodies in Kwe Field, coastal swamp depobelt, onshore eastern Niger Delta Basin were evaluated from a composite log suite comprising gamma ray, resistivity, density and neutron logs of five (5) wells with core photographs of one (1) reservoir of one well. The aim of the study was to evaluate the petrophysical properties of the reservoirs while the objectives were to identify the depositional environment and predict the reservoir system quality and performance. The study identified three reservoir sand bodies in the field on the basis of their petrophysical properties and architecture. Reservoir A has an average NTG (61.4\%), Ø (27.50\%), K (203.99 md), $S_{\mathrm{w}}(31.9 \%)$ and $\mathrm{S}_{\mathrm{h}}(68.1 \%)$; Reservoir B has an average NTG (65.6\%), Ø (26.0\%), K (95.90 md), $\mathrm{S}_{\mathrm{w}}(28.87 \%)$ and $\mathrm{S}_{\mathrm{h}}(71.13 \%)$ while Reservoir C has an average NTG (70.4\%), Ø (26.1\%), K (91.4 md), $\mathrm{S}_{\mathrm{w}}(25.0 \%)$ and $\mathrm{S}_{\mathrm{h}}(75.03 \%)$ and therefore show that the field has good quality sandstone reservoirs saturated in hydrocarbon. However, the presence of marine shales (or mudstones) interbedding with these sandstones may likely form permeability baffles to vertical flow and compartmentalize the reservoirs. These reservoirs may therefore have different flow units. Integrating wireline logs and core data, the reservoir sand bodies were interpreted as deposited in an estuarineshoreface setting thus indicating that the Kwe Field lies within the marginal marine mega depositional environment. CJASEM
\end{abstract}

http://dx.doi.org/10.4314/jasem.v20i2.21

Key words: Estuarine, Shoreface, Reservoir, Sand, Kwe, field

\section{Introduction}

The Niger Delta Basin has been known as one of the world's most prolific petroleum producing Tertiary deltas (Selley, 1997) and has been ranked the $12^{\text {th }}$ largest known accumulation of recoverable hydrocarbons, with reserves exceeding 34 billion barrels of oil and 93 trillion cubic feet of gas (Tuttle $e t$ al., 1999). Ever since the commencement of commercial hydrocarbon production in this basin by Shell-BP in 1958 (Weber, 1971), there has been an overwhelming concentration of exploration activities as well as scientific researches.

Previous work by Short and Stauble (1967) outlined the general geology of the Niger Delta by dividing the stratigraphy into three distinct units (the Akata Formation, the Agbada Formation and the Benin Formation) and set the stage for more investigation into the deltaic deposits. Evamy et al. (1978) on their part, researched into the hydrocarbon habitat of the basin and identified two possible migration pathways; one along the structure building faults which terminate in the Akata Formation; and the other, migrating from the seaward facies and changes up dip into the rollover structures. A more recent work by Nton and
Adesina (2009) who investigated some aspects of structures and depositional environment of sand bodies within the Tomboy Field, offshore part of the basin noted that the reservoir sands were deposited in different environments consisting of distributary channels, mouth bars, barrier island and tidal channels, and were deposited across normal growth faults and anticlinal structures.

On the petrophysical evaluation of the reservoir sands, Ulasi et al. (2012), Omoboriowo et al.(2012); Rotimi et al. (2013); Alao et al. (2013), and Mode et al. (2015) have independently investigated the Uzek well, offshore depobelt; Amma field in onshore eastern part; Bob field, in south eastern onshore part; Apete field, in offshore part; and DC70X reservoirs of Mbakan field in the central part of the basin respectively, and noted that the petrophysical properties of the reservoirs sands of the Niger Delta are high enough to permit hydrocarbon production.

With the increasing demand of hydrocarbon products to meet global needs in the $21^{\text {st }}$ century despite the fall in global oil price, there is however need for more research on the petrophysical and depositional 
environments of other fields with a view to increasingly support reservoir appraisal, development and thus optimize hydrocarbon production from the basin. This work is therefore aimed at the petrophysical evaluation of the Kwe Field, located in the coastal swamp depobelt, onshore Eastern Niger Delta Basin and thus, is a scientific contribution towards supporting hydrocarbon production programme in the basin. The objectives of the study were to identify the depositional environment, estimate and compare the porosity, permeability and water saturation distribution within the field, identify specific reservoir sand bodies, and predict the reservoir system quality and performance.

\section{MATERIALS AND METHODS}

Geological Setting: The Kwe Field (Figs.1 and 2) is located in the eastern Niger Delta province which comprises the eastern (or Atlantic) session of the coastal south-south Nigeria and stretches from the Akassa River eastwards to the Cross River area.

The Niger Delta is a marginal sag basin located in the continental margin of the Gulf of Guinea in equatorial West Africa, covering an area of about $75,000 \mathrm{~km}^{2}$, with an average thickness of about $12 \mathrm{~km}$ and lies between latitudes $3^{\circ}$ and $6^{\circ} \mathrm{N}$ and longitudes $5^{\circ}$ and $8^{\circ} \mathrm{E}$ (Knox and Omatsola, 1989).

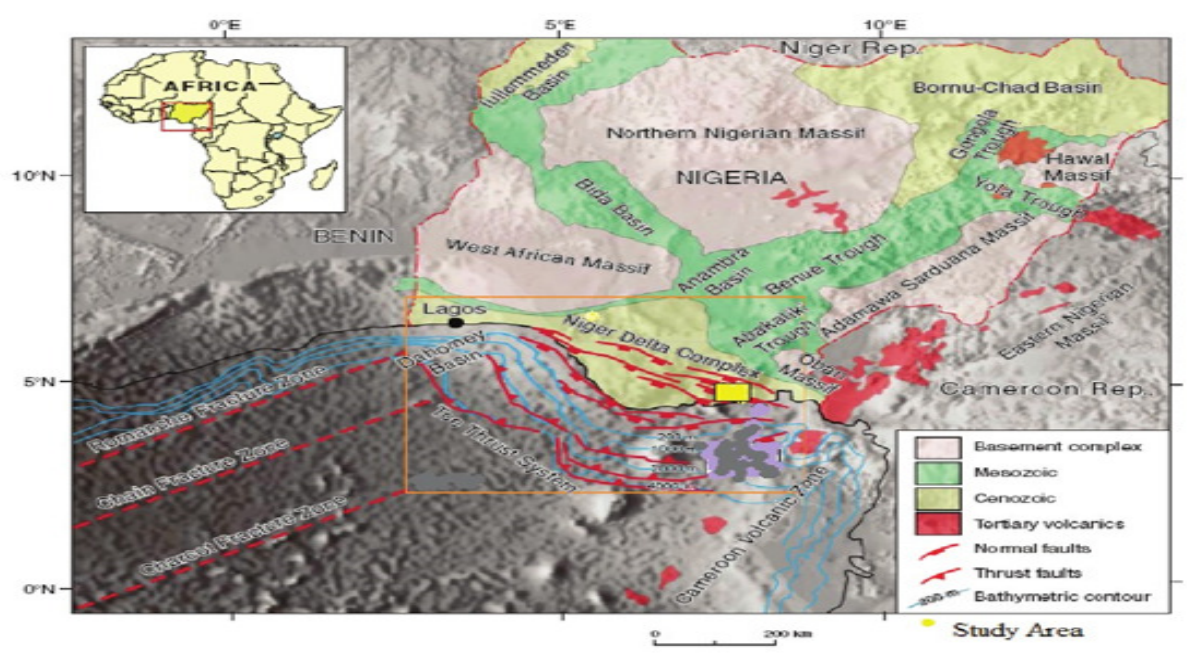

Figure 1: Location map of study area (after Corredor et al., 2005)

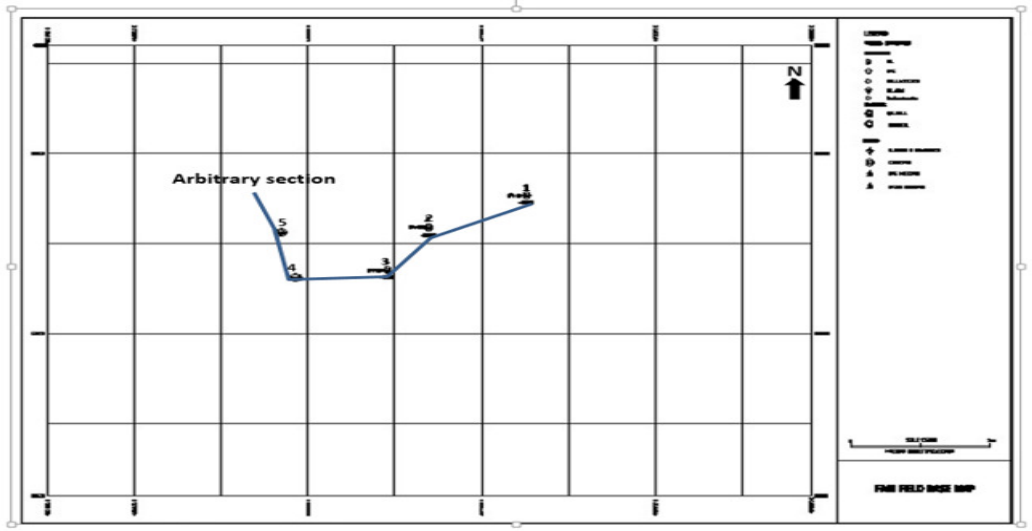

Figure 2: Base Map of the study Area

It is bounded in the western -north western part by the Okitipupa Hinge line; in the north by the Benin Flank; in the north eastern part by the Abakaliki High; and in the eastern - south eastern part by the Calabar Flank. The offshore boundary of the province towards the east is bounded by the Cameroon volcanic line while the southern to south western flank is defined by the 4000 - metre bathymetric contour in areas with great sediment thickness 
(Corredor et al., 2005). The formation of the basin has also been related to the separation of Africa from South America and the consequent opening of the South Atlantic in Mid Cretaceous times (Evamy et al., 1978; Doust and Omatsola, 1990).

\section{METHODOLOGY}

The following materials: field map, base map and a composite log suite comprising gamma ray, resistivity, density and neutron logs of five (5) wells with core photographs of one (1) reservoir of one well were provided by Shell Petroleum Development Company for which the authors are grateful.

The gamma ray log motif for the cored section was used to calibrate and constrain the interpretation for the uncored section. The gamma ray log was thereafter integrated with other logs in the composite suite to evaluate the hydrocarbon bearing reservoir sands.

The core photographs of the reservoir of the well (well 4) provided were studied and described from bottom to top. The visible facies characteristics observed on the photos, particularly, the lithology, sedimentary structures (cross bedding, lamination and bioturbation) and geological succession were studied. Based on these, lithofacies types and associations were determined and interpreted. From the composite log suite provided, the shapes of gamma ray log were noted and further used to constrain the character of the sedimentary facies and depositional environment based on the views of Scholle and Spearing (1998) and Coleman and Prior (1980).

For the petrophysical parameters, equations 1- 11 were used to evaluate the values obtained from logs and thereafter compared with the standard values so as to characterize the reservoirs.

The porosity values of the reservoirs were estimated from the density and neutron porosity logs via equations $1-5$ and thereafter, results obtained from the calculations were compared with standard values which have been used to characterize the porosity of reservoir rocks in parts of the Niger Delta Basin as excellent $(>30 \%)$, very good $(20-25 \%)$, good (15$20 \%$, poor $(5-10 \%)$ and negligible (0-5\%) (EtuEfeotor, 1997).

$$
\begin{aligned}
& \mathrm{IGR}=\underline{\mathrm{GR}}_{\log }-\mathrm{GR}_{\min } \ldots \ldots \ldots \text { Equation } 1 \\
& \mathrm{GR}_{\text {max }}-\mathrm{GR}_{\text {min }} \\
& \mathrm{V}_{\mathrm{sh}}=0.083\left[2^{(3.7 \times 1 \mathrm{GR})}-1\right] \ldots \ldots \ldots . . \text { Equation } 2 \text {, } \\
& \Phi_{\mathrm{D} \text { corr }}=\left[\frac{\rho m a-\rho b}{\rho m a-\rho f}\right]-\mathrm{V}_{\mathrm{sh}}=\left[\frac{\rho m a-\rho s h}{\rho m a-\rho f}\right] \ldots \text { Equation } 3 \\
& \Phi_{\mathrm{N} \text { cor }}=\Phi_{\mathrm{N}}-\left[\frac{\Phi \mathrm{N} \text { clay }}{0.45} \times 0.30 \times \mathrm{V}_{\mathrm{sh}}\right] \ldots . . \text { Equation } 4,
\end{aligned}
$$

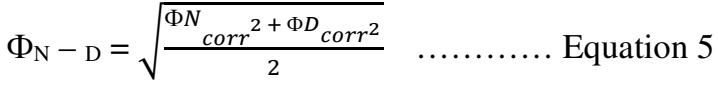

Where: IGR $=$ Gamma Ray Index

$$
\begin{aligned}
& \mathrm{GR}_{\max }=\text { maximum gamma ray reading }(100 \% \text { shale }) \\
& \mathrm{GR}_{\text {min }}=\text { minimum gamma ray reading [clean sand or } \\
& \quad \text { Carbonate] } \\
& \mathrm{GR}_{\mathrm{log}}=\text { gamma ray reading of formation } \\
& \left.\rho \mathrm{ma}=\text { matrix density (sand matrix }=2.648 \mathrm{~g} / \mathrm{cm}^{3}\right) \\
& \rho \mathrm{f}=\text { density of formation fluid (fresh mud }=1.0) \\
& \rho \mathrm{b}=\text { bulk density (read from log) } \\
& \rho \mathrm{sh}=\text { bulk density of adjacent shale } \\
& \mathrm{Vsh}=\text { volume of shale, } \\
& \Phi_{\mathrm{N}}=\text { neutron porosity of adjacent shale } \\
& \Phi_{\mathrm{N}}-\text { D }=\text { neutron }- \text { density combination } \\
& \Phi_{\mathrm{N} \text { corr }}=\text { neutron porosity corrected for the effect of } \\
& \text { shale } \\
& \Phi_{\mathrm{D} \text { corr }}=\text { density porosity corrected for the effect of } \\
& \text { shale. }
\end{aligned}
$$

The permeability values of the reservoirs were derived from equation (6) and thereafter, results obtained from the calculations were also compared with standard values which have been used to characterize the permeability of reservoir rocks in parts of the Niger Delta Basin as excellent (>1000 md), very good (250$1000 \mathrm{md})$, good $(50-250 \mathrm{md})$, moderate $(15-50 \mathrm{md})$ and poor to fair $(<10-15 \mathrm{md})$ (Etu-Efeotor, 1997).

$$
(\mathrm{K})=\frac{0.136 \times \Phi^{44}}{s_{w i r r^{2}}} \ldots \ldots \ldots \ldots \ldots \ldots \ldots \ldots \ldots \ldots \text { Equation } 6
$$

Where: $\Phi=$ porosity

$$
S_{\text {wirr }}{ }^{2}=\text { irreducible water saturation }
$$

The Net to Gross (NTG) thickness of each of the units was calculated from equation 7

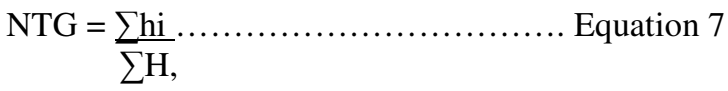

Where: $\sum$ hi $=$ summation of individual sand units only $\sum \mathrm{H}=$ the whole unit/reservoir consisting of both sand and non-sand unit

The Fluid saturation of the reservoir rock was determined as follows:

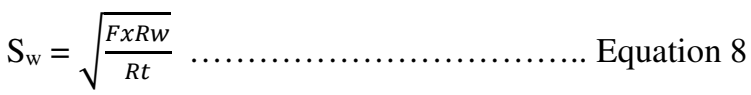

(Archie, 1942)

$$
\mathrm{F}=a / \Phi^{m}=\frac{0.62}{\Phi 2.15} \ldots \ldots \ldots \ldots \ldots \ldots \ldots \ldots \ldots \ldots \ldots \ldots \ldots \ldots+\text { Equation } 9
$$




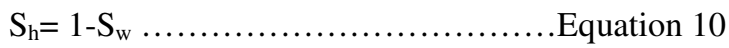

Where $R_{w}=$ resistivity of the formation water

$R_{t}=$ The true resistivity of the zone of interest

$\mathrm{F}=$ formation factor.

$\mathrm{S}_{\mathrm{w}}=$ water saturation

$\mathrm{S}_{\mathrm{h}}=$ hydrocarbon saturation

$\mathrm{m}=$ cementation factor $=2$

$\Phi=$ porosity

$\mathrm{a}=$ constant

The bulk volume of water (BVW) was calculated as the product of the formation's water saturation $\left(S_{\mathrm{w}}\right)$ and its porosity $(\Phi)$

$\mathrm{BVW}=\mathrm{S}_{\mathrm{W}} \times \Phi$ Equation 11
Finally, from the thickness of the reservoirs obtained (by subtracting the base from the top of the reservoir), isopach map was constructed from which the geometry of the reservoirs as well as the dip and strike directions were inferred.

\section{RESULTS AND DISCUSSION}

Geological Core Analysis: Three reservoir sands labeled A, B and C were identified in the Kwe Field from the data set provided. These were correlated across five wells (Fig. 3) of which only reservoir C of well 4 which lies within 12900 - $13300 \mathrm{ft}$. (3931.9 $4053.8 \mathrm{~m}$ ) was cored and is described on the basis of lithofacies and sedimentary structures.

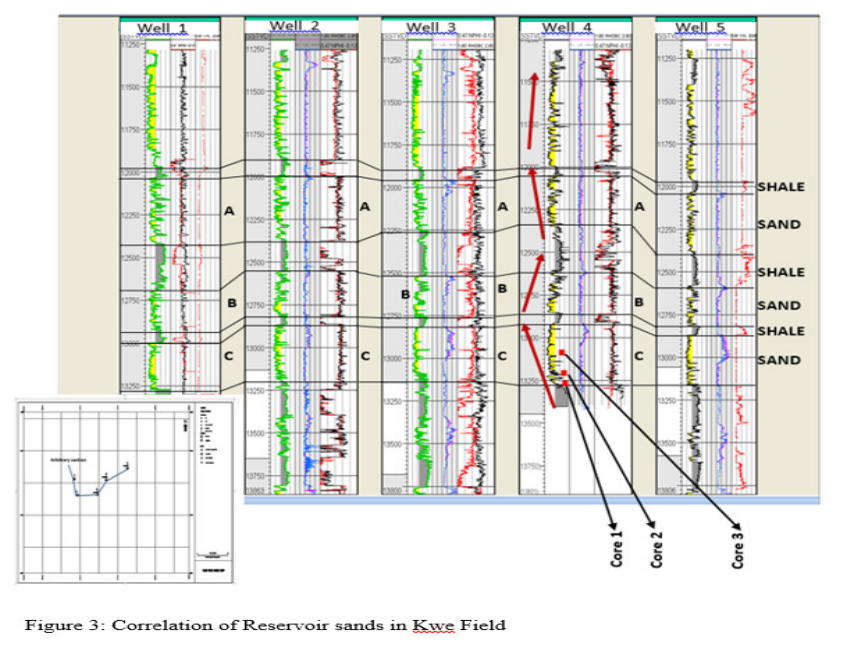

Core 1, Reservoir C, Well 4 (13250.0 - 13256.0ft.or 4038.6 - 4040.4m):

This core (Fig. $4^{1}$ ) is characterized by bioturbated, hummocky and swaley cross bedded sandstone. The hummocky and swaley cross bedding, though has been strongly obliterated by bioturbation, relicts can however be observed at a closer look, particularly at the upper section of the core. The intensity of the burrows increases upsection and are somewhat mottled with dark organic material. On the gamma-ray $\log$ (Fig. 3), this section shows a serrated funnel shape and exhibits a coarsening-upward grain-size profile.

The presence of hummocky and swaley cross bedding is indicative of deposition by storm waves in the outer shoreface and transition zone between fair weather wave-base and storm wave-base (Yagishita et al., 1992; Monaco, 1994; Tucker, 2003). Additionally, the presence of Ophiomorpha reflects a well-oxygenated and nutrient-rich setting and such setting are commonly found within the shoreface environment, particularly at the lower-middle shoreface environment (Freyet al., 1978; Boggs, 2001; Mude, 2011).

Core 2, Reservoir C, Well 4 (13195.0-13201.0ft. or 4021.8-4023.7 m)

This core (Fig. $4^{2}$ ) is characterized by parallel, ripple cross laminated sandy heteroliths to low angle cross bedded sandstone. On the gamma-ray log, this section shows a serrated funnel shape and exhibits a coarsening-upward grain-size profile thus indicative of interbedded sand and shale deposition with sand to shale ratio increasing upwards.

The presence of parallel to ripple laminated sandy heteroliths suggests deposition in tidally influenced subaqueous environments under fluctuating flow conditions (Nwachukwu, et al., 2011). Such environments are often characterized by high flow velocity (caused by high tidal action) alternating with slack water stage during period of low tidal influence. Deposition of sand is favoured during period of high tidal current with high flow conditions whereas, at low 
tide, energy is weak and therefore favours shale or clay deposition (Archer and Kvale, 1989; Hettinger, 1995; Shanley et al., 1992). Although such settings may range from coastal to deep marine (Boggs, 2001;

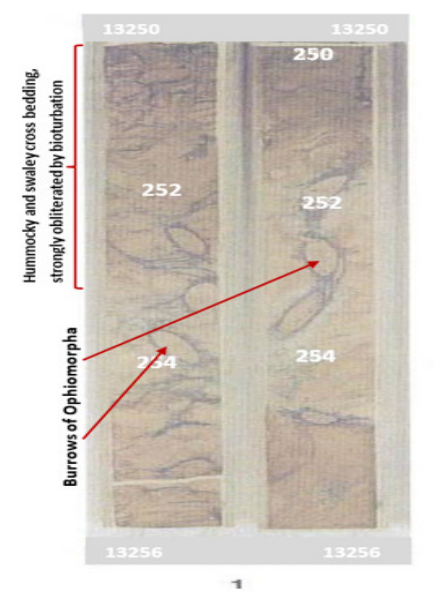

sheikh et al., 2006; Roberts, 2007), however, the presence of low angle cross-bedding, couple with its association with core 1 and 3, suggests its deposition in upper to middle shoreface environment.

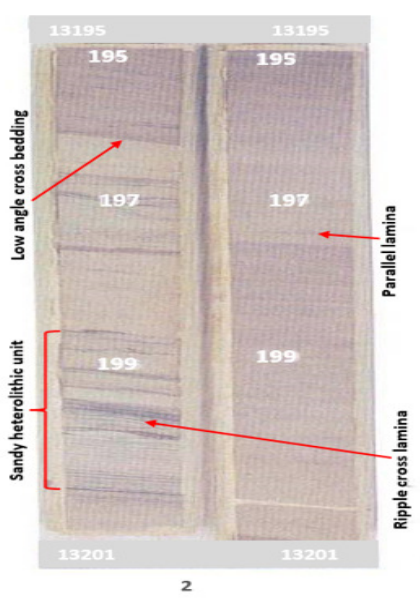

finning upward succession that is characteristic of channel fills.

It should however be noted that though unidirectional paleocurrent pattern is indicative of fluvial channel (Boggs, 2001), tidally influenced channel such as a tidal channel or estuarine channel dominated by ebb flow or flood current could produce a unimodal paleocurrent pattern as the ebb and flood often find different dominant pathways (Bjørlykke, 2010). 


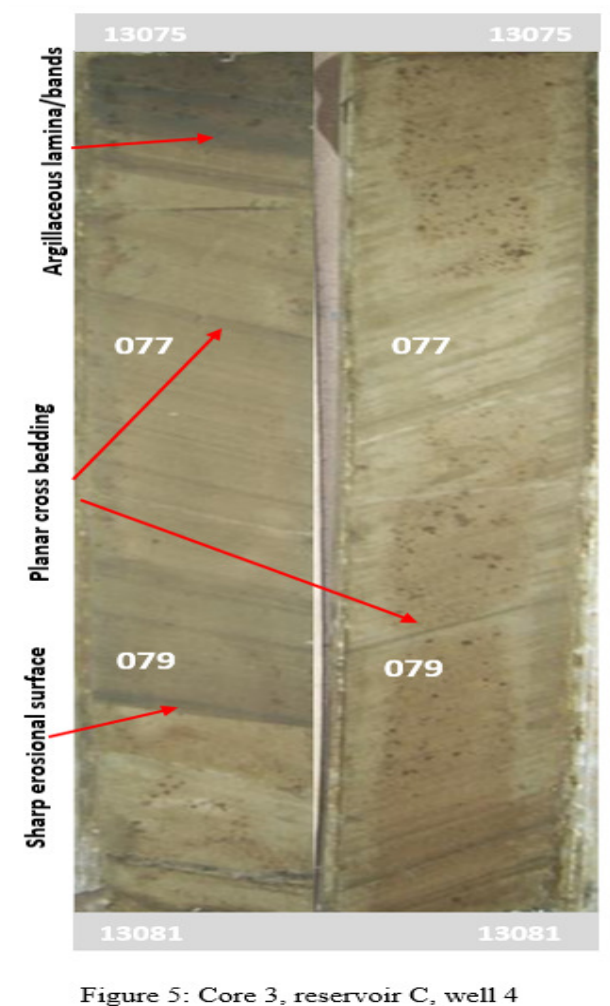

\section{Reservoir Architecture and Depositional Model of Reservoir ' $C$ ' in Kwe Field}

As shown on Figure 6, a fluvially dominated estuarineshoreface depositional setting has been proposed by this research as the reservoir architecture and depositional model for the reservoir ' $\mathrm{C}$ ' in Kwe Field based on core description and interpretation of well logs. Furthermore, by using similar gamma ray log motif in cored section as calibration for the uncored section, the Gross Depositional Environment (GDE) of the Kwe field was interpreted as ranging from coastal setting to shallow marine. The gamma ray log motif of the five wells presented for the Kwe Field shows successions of stacked channels interbedded by marine shales and are indicative of deposition by transgressive and regressive phases of the delta build up. With regards to reservoir ' $\mathrm{C}$ ' however, its lithofacies and associations were deposited in a shallow marine (shoreface) depositional setting incised by fluvial dominated estuarine channels. Estuarine channel genetic units have been described by Boggs (2001) and Scholle and Spearing (1998) as consisting of a mixture of marine (shoreface)reworked sand (lower part) and subordinate fluvial sand (upper part) filling channels near the mouth of the estuary; and a sharp erosive base with interbedded silts and muds indicative of fluctuating flow conditions. On the log motif, Scholle and Spearing (1998) further noted that estuarine channel units are characterized by stacked log profiles typically blocky to bell-shaped and often reflects the hybrid of marine and fluvial depositional environments. 


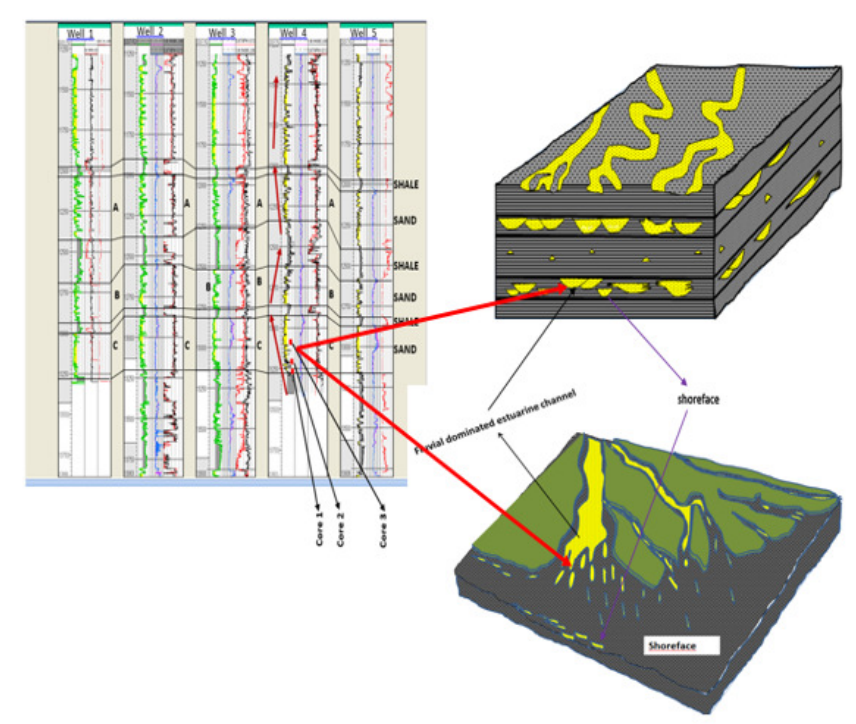

Figure 6: Conceptual Depositional model of reservoir ' C', Kwe Field

Petrophysical Evaluation: Results of petrophysical evaluation of the three reservoir sands labeled A, B and $\mathrm{C}$ based on the available dataset are shown on Table 1 and are discussed:

\section{Reservoir A}

This occurs at a depth range of 11950 - $12425 \mathrm{ft}$. (3642.4-3787.1 m) with an average gross thickness of $101.6 \mathrm{~m}$, average net sand thickness of $62.3 \mathrm{~m}$ and average net to gross thickness of $61.4 \%$. The porosity of the reservoir ranges from $25-32 \%$ with an average value of $27.50 \%$ while permeability rages from 169.36 - $269.76 \mathrm{md}$ with an average value of 203.99 md. These values, when compared with the qualitative evaluation of reservoir porosity and permeability on standard charts (Etu-Efeotor, 1997) show that the reservoir has very good to excellent porosity with good permeability. Furthermore, the water saturation ranges from $21.7-45.2 \%$ with an average value of $31.90 \%$ while the hydrocarbon saturation ranges from $54.8-78.2 \%$ with an average value of $68.10 \%$ and therefore shows that the reservoir has a good hydrocarbon saturation. However, the presence of marine shales (mudstones) as indicated by high gamma spikes on gamma log (Fig 3) and heterolithic unit (Fig $4^{2}$ ) interbedding with the sandstones are likely to form permeability baffles to vertical flow and compartmentalize the reservoirs. Reservoir ' $A$ ' may therefore have different flow units arising from the interbedding of the reservoir sandstones with the shale (or mudstones).

\section{Table 1: Results of Petrophysical Analysis of Reservoir sands in Kwe Field}




\section{Reservoir B}

This occurs at a depth range of 3817.6 - 3947.2 m with an average gross thickness of $78.7 \mathrm{~m}$, average net sand thickness of $52.0 \mathrm{~m}$ and average net to gross thickness
This occurs at a depth range of $3909.1-4046.2 \mathrm{~m}$ with an average gross thickness of $100.3 \mathrm{~m}$, average net sand thickness of $71.3 \mathrm{~m}$ and average net to gross thickness of $70.4 \%$. The porosity of the reservoir

\begin{tabular}{|c|c|c|c|c|c|c|c|c|c|c|}
\hline \multirow{2}{*}{$\begin{array}{l}\text { Well } \\
\text { Name }\end{array}$} & \multirow{2}{*}{$\begin{array}{l}\text { Reservoir } \\
\text { zone }\end{array}$} & \multirow{2}{*}{$\begin{array}{l}\text { Depth } \\
\text { (m) }\end{array}$} & \multirow{2}{*}{$\begin{array}{l}\text { Gross } \\
\text { thickness } \\
\text { (m) }\end{array}$} & \multirow{2}{*}{$\begin{array}{l}\text { Net } \\
\text { Thicknes } \\
\text { s } \\
\text { (m) }\end{array}$} & \multirow{2}{*}{$\begin{array}{l}\text { Net- Gross } \\
\text { Thickness (\%) }\end{array}$} & \multirow{2}{*}{$\begin{array}{l}\text { Porosity } \\
\Phi(\%)\end{array}$} & \multirow{2}{*}{$\begin{array}{l}\text { Permeability } \\
\text { k (md) }\end{array}$} & \multicolumn{2}{|c|}{ Water saturation (\%) } & \multirow{2}{*}{$\begin{array}{l}\text { HC saturation } \\
(\%)\end{array}$} \\
\hline & & & & & & & & Average & Irreducible & \\
\hline \multirow[t]{3}{*}{2} & A & $3657.6-3771.9$ & 114.3 & 72.0 & 63.0 & 25.0 & 169.4 & 45.2 & 8.2 & 54.8 \\
\hline & B & $3825.2-3909.1$ & 83.9 & 64.2 & 76.5 & 22.8 & 39.4 & 38.6 & 8.9 & 61.4 \\
\hline & $\mathrm{C}$ & $3924.3-4023.4$ & 99.1 & 64.4 & 65.0 & 22.2 & 25.4 & 32.4 & 8.9 & 67.6 \\
\hline \multirow[t]{3}{*}{3} & A & $3642.4-3741.4$ & 99.0 & 51.4 & 51.9 & 25.4 & 172.9 & 21.7 & 8.3 & 78.3 \\
\hline & B & $3817.6-3893.8$ & 76.2 & 45.5 & 59.7 & 25.2 & 69.2 & 23.3 & 7.9 & 76.7 \\
\hline & $\mathrm{C}$ & $3909.1-4000.5$ & 91.4 & 58.7 & 64.2 & 25.9 & 60.1 & 16.2 & 7.7 & 83.8 \\
\hline \multirow[t]{3}{*}{4} & A & $3672.8-3764.3$ & 91.5 & 63.4 & 69.3 & 32.1 & 269.8 & 28.8 & 6.0 & 71.2 \\
\hline & B & $3871.0-3947.2$ & 76.2 & 46.2 & 60.6 & 30.0 & 179.0 & 24.7 & 6.5 & 75.3 \\
\hline & $\mathrm{C}$ & $3935.7-4046.2$ & 110.5 & 90.7 & 82.1 & 30.1 & 188.8 & 26.3 & 6.4 & 73.7 \\
\hline
\end{tabular}

of $65.6 \%$. The porosity of the reservoir ranges from $22.8-30.0 \%$ with an average value of $26.0 \%$ while permeability rages from $39.44-179.02 \mathrm{md}$ with an average value of $95.90 \mathrm{md}$. These values, in comparison with qualitative evaluation of reservoir porosity and permeability on standard charts (EtuEfeotor, 1997) also show that this reservoir has very good porosity with good permeability. Furthermore, the water saturation ranges from $23.3-24.7 \%$ with an average value of $28.87 \%$ while the hydrocarbon saturation ranges from $61.4-76.7 \%$ with an average value of $71.13 \%$ and also shows that the reservoir has a good hydrocarbon saturation. However, like reservoir A, the presence of marine shales (mudstones) interbedding with the sandstones may likely form permeability baffles to vertical flow and compartmentalize the reservoirs. Reservoir ' $\mathrm{B}$ ' may therefore have different flow units arising from the interbedding of the reservoir sandstones with the shale (or mudstones). ranges from $22.2-30.1 \%$ with an average value of $26.1 \%$ while permeability ranges from $25.4-188.8$ md with an average value of $91.4 \mathrm{md}$. These values, also when compared with qualitative evaluation of reservoir porosity and permeability on standard charts (Etu-Efeotor, 1997) also show that this reservoir has very good porosity with good permeability. The water saturation ranges from $16.2-32.4 \%$ with an average value of $25.0 \%$ while the hydrocarbon saturation ranges from 67.6 - $83.8 \%$ with an average value of $75.03 \%$ and therefore shows that the reservoir has a good hydrocarbon saturation. Further contouring of the top of this reservoirs (fig. 7) shows that this reservoir has good anticlinal trap. However, like the other two reservoirs, the presence of marine shales interbedding with the sandstones may likely form permeability baffles to vertical flow and compartmentalize the reservoirs. Reservoir ' $C$ ' may also have different flow units arising from the interbedding of the reservoir sandstones with the shale.

\section{Reservoir C}




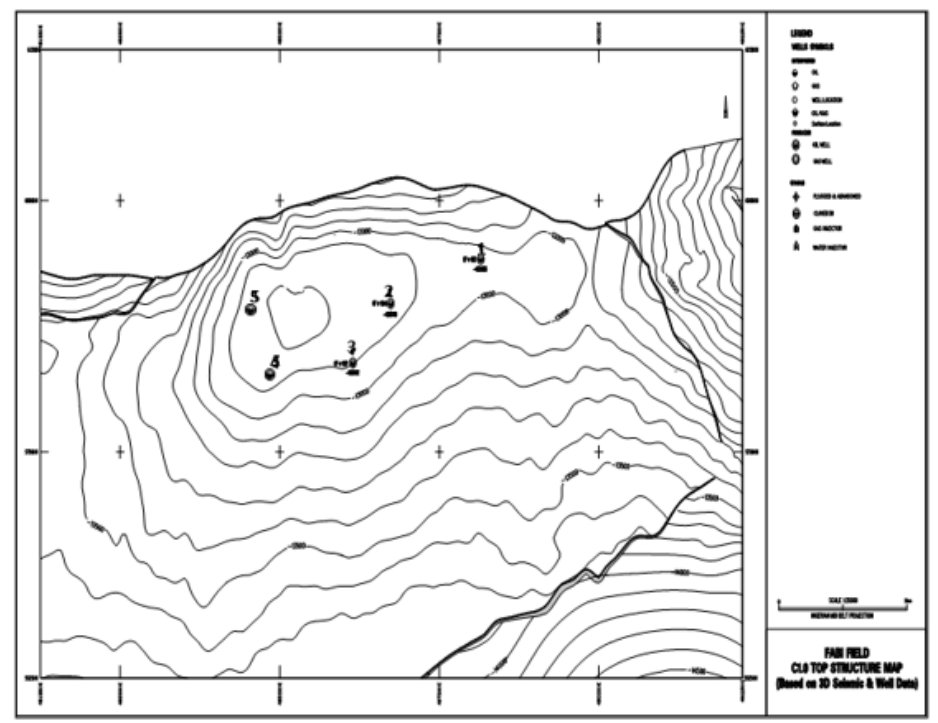

Figure 7: Contour Map of the top of Reservoir ' $\mathrm{C}$ '

Conclusion: Three reservoir sand bodies labeled A, B, and $\mathrm{C}$ were identified and evaluated in the Kwe Field. These reservoir sand bodies were interpreted as deposited in an estuarine-shoreface setting thus indicating that the Kwe Field lies within the marginal marine mega depositional environment. These reservoir sand bodies have good reservoir characteristics as shown by their petrophysical properties. Contour map of the top of reservoir ' $\mathrm{C}$ ' shows that the reservoir has good anticlinal trap. However, the presence of marine shales (or mudstones) interbedding with the sandstones are likely to form permeability baffles to vertical flow and compartmentalize the reservoirs. These reservoirs may therefore have different flow units. The study however recommends that the interpreted depositional environment should further be constrained with biostratigraphic data as they were not made available for this study. Additionally, thin-section petrographic characterization and clay mineral studies of the identified lithofacies should be studied so as to further determine the reservoir quality of these reservoir sandstone as well as accessing the seal potentials.

Aknowledgement: The dataset for this research were provided by the Shell Petroleum Development Company (SPDC) through the Department of Petroleum Resources (DPR) for this research for which the authors are grateful

\section{REFERENCES}

Alao, P.A., Ata, A.I., and Nwoke, C.E. (2013). Subsurface and Petrophysical Studies of Shalysand reservoir targets in Apete Field, Niger Delta, Journal of Environment and Earth Science, vol. 2 (3), p 56-72

Archer A.W. and Kvale E.P. (1989). Seasonal and yearly cycle within tidally laminated sediments: an example from the Pennsylvanian in Kentucky, Indiana and Illinois,Indiana geological Survey, Illinois Basin consortium, No 1, 45-46.

Archie C.E. (1942). Introduction to petrophysics of reservoir rocks, American association of petroleum geology bulletin 34(5), 943-961.

Bjørlykke, (2010). Petroleum Geoscience: From sedimentary environment to rock physics; Springer-Verlag Berlin Heidelberg, p70-78

Boggs S (2001). Principles of Sedimentary and stratigraphy; Prentice Hall, Upper Saddle River, New Jersey, $3^{\text {rd }}$ ed, p59-415.

Coleman, J.M. and Prior, D.B. (1980). Deltaic Sand Bodies, AAPG Continuing Education Course Note, Series No 15, p56-60

Corredor, F., Shaw, J. H. and Bilotti, F. (2005). Structural styles in the deep water fold and thrust belts of the Niger Delta, American Association of Petroleum Geologists Bulletin (AAPG), Vol. 89 (6), p 753-780 
Doust, H andOmatsola, E (1990).Niger Delta. In: J. D. Edwards and P.A. Santogrossi (Eds.), Divergent/passive Margin Basins, American Association of Petroleum Geologists Memoir 48, Tulsa, Oklahoma, USA, p 239-248

Etu-Efeotor J.O. (1997).Fundamentals of petroleum geology; paragraphics, Port Harcourt, Nigeria pp. 51-63.

Evamy B.D., Haremboure J., Kamarling P., Knaap W.A. Mollry, F.A and Rowland, P. (1978).Hydrocarbon habitat of Tertiary Niger Delta, AAPG bull, Vol. 63 (1), p 1-39.

Frey, R.W., Howard, J.D., and Pryor, W.A. (1978). Ophiomorpha: Its Morphology, Taxonomy and Environmental Significance, Paleogeography, Paleoclimatology and Paleoecology, Elsevier Scientific Publishing Company, Amsterdam, vol. 23, 199-229

Hettinger R.D. (1995).Sedimentological Descriptions and Depositional Interpretation in sequence stratigraphic context of two 300 meter cores from upper cretaceous straight cliffs formation, KaiparowitsPlateau, Kane County, Uttah. US, Geology Survey Bulletin 2115-A, 29-33.

Knox, G. J. and Omatsola, M. E. (1989). Development of the Cenozoic Niger Delta in terms of the "escalator regression model" and impact on hydrocarbon distribution; proc. KNGMG symposium on Coastal Lowlands, Geology and Geotechnology, Dordrecht, Kluwer; P181-202

Mode, A.W., Anyiam, A.W. and Omuije, J.O. (2015). Analysis of Sedimentary facies and Paleodepositional environments of the Dc70X reservoir in Mbakan field, Central Swamp, Niger Delta, Arabian Journal of Geoscience, vol. 8 (9), p 7435 7443

Monaco, P. (1994). Hummocky cross-stratification and trace fossils in the Middle Toarcian of some sequences of Umbria-Marche Apennines, Geobios, Elsevier Scientific Publishing Company, Amsterdam, vol. 27 (3), pp 679-688

Mude, S.N. (2011): Paleoenvironmental significance of ichnofossils from the Chaya Formation, Porbarder Group, Southwest Coast, India, Greener Journal of Physical Sciences, vol. 1 (1) p 29-36
Nton, M.E. and Adesina, A. D., (2009). Aspects of structures and depositional environment of sand bodies within Tomboy field, offshore western Niger Delta, Nigeria; Materials and Geoenvironment, Vol. 56, No. 3, pp. 284-303.

Nwachukwu, U.E.D; Anyiam, O.A; Egbu, O.C. and Obi, I.S. (2011). Sedimentary controls on the reservoirs properties of the Paleogene-fluviotidals sands of the Anambra Basin Southeastern Nigeria: Implication for deep water reservoir studies, Ame. Journ.Sci and Ind., Res. Vol 2, p3748.

Omoboriowo, A.O., Chiadikobi, K.C., and Chiaghanam, O.I. (2012). Depositional Environment and Petrophysical characteristics of 'LEPA' reservoirs, Amma Field, Eastern Niger Delta, International Journal of Pure and Applied Science and Technology, 10 (2), p 38-61

Roberts, E.M. (2007). Facies architecture and depositional environment of the Upper Cretaceous Kaiparowits Formation, Southern Utah, Sedimentary Geology, Elsevier Scientific Publishing Company, Amsterdam, vol197, p 207233

Rotimi, O.J., Adeoye, T. O and Ologe, O. (2013). Petrophysical Analysis and Sequence Stratigraphy: Apraisal from well logs of 'Bob' field, South-Eastern Niger delta, Journal of Emerging trends in Engineering and Applied Science (JETEAS), 4 (2), p 219-225

Scholle P.A. and Spearing D. (1998).Sandstone Depositional Environments; AAPG Memoir 31, p115-328.

Selley R.C. (1997). African Sedimentary Basins of the World; Elsevier Science, Amsterdam, pp. 151172.

Shanley K.W., McCabe P.J., and Hetlinger R.D. (1992). Tidal influence in Cretaceous fluvial strata from Utah, U.S.A.: A key to sequence stratigraphic interpretation, Sedimentology, vol 39, 900-935.

Sheikh, K.S., Khan, A. and Farooqui, M.A. (2006). Steep depositional slope and absence of back barrier: The controlling factors of complex lithofacies association in a foreshore beach environment, Journal of Himalayan, earth Sciences, vol. 39, p 15-38 
Short, K.C and Stauble, A.J (1967). Outline of Geology of the Niger Delta, American Association of Petroleum Geologists Bulletin, Vol 51, p 761-779

Tucker, M.E. (2003). Sedimentary Rocks in the Field, $3^{\text {rd }}$ ed., John Wiley and Sons Ltd., p 120-121

Tuttle, M. L. W., Charpentier, R. R., and Brownfield, M. E. (1999). The Niger Delta Petroleum System: Niger Delta Province, Nigeria, Cameroon, and EquatorialGuinea, Africa: USGS Open-file report 99-50-H, p 7.
Ulasi, A.I., Onyekuru, S.O., and Iwuagwu, C.J. (2012). Petrophysical evaluation of Uzek well using $\log$ and core data, offshore Depobelt, Niger Delta, Nigeria, Applied Science Research, Pelagia Research Library, vol. 3(5), 2966-2991.

Weber, K.J. (1971).Sedimentological aspects of oil fields in Niger Delta; Geologize enMingbouw, vol. 50, pp.559-576.

Yagishita, K., Arakaw, S., and Taira, A. (1992). Grain fabric of hummocky and swaley crossstratification, Sedimentary Geology, Elsevier Scientific Publishing Company, Amsterdam, vol. 78 (3-4), p 181-18 